\title{
Recognising community rights
}

\section{The potential and challenges of forest tenure reform}

\section{Key points}

- Forest tenure reform differs from agrarian reform. Besides responding to livelihood demands, it also explicitly aims to conserve forests, and is often driven by demands for ancestral or customary land rights.

- Formal forest-tenure rights have been combined with burdensome responsibilities to protect forests-based on norms established by the state even when there are effective local customs.

- Communities expend scarce human and financial resources in their efforts to defend their new rights from ongoing encroachment.

- Forest tenure reform has demonstrated its potential to improve livelihoods and conserve forests; to fully support livelihoods improvement, policy makers can build on community strengths and local rule making, and facilitate community capacity, empowerment and market access, rather than always to impose external norms and regulations.

\section{Introduction}

Rural people have lived in and around forests for millennia, but state policies have often failed to grant communities formal rights to those forests. This may finally be changing. In a number of countries in Africa, Asia and Latin America, governments are beginning to recognise tenure rights for indigenous peoples and other forestbased communities. ${ }^{1}$
Forest tenure refers to the social relations and institutions governing the use and control of forest land and resources; it determines who is allowed to use which resources, in what way, for how long and under what conditions. Though the world's forests are still primarily public lands, formally owned by the state, more than a quarter of forests in developing countries are now owned by or assigned to communities. The bulk of this shift has occurred since 1985 , with an increase from $22 \%$ to $27 \%$ between 2002 and 2008 (Sunderlin et al. 2008).

This change in tenure rights in forested areasrepresenting a 'forest reform' comparable to the widespread agrarian reforms of the mid-20th century - warrants serious consideration. This infobrief presents the results of research into this reform (see Box 1 and Figure 1). What is the nature of this forest reform, and why is it occurring? What are the forces shaping this new trend? How is it unfolding, and what are the challenges that communities continue to face? How has it affected forests and livelihoods?

\section{Defining tenure rights}

Tenure rights to natural resources are usually understood as a bundle of rights ranging from simple rights of access, to use, management, exclusion and alienation. The first two rights, access and use, refer to the right to enter an area and to remove or withdraw resources. The last three are the most important in terms of reforms, because they constitute decision-making rights. Management refers to 'the right to regulate internal use patterns or transform the resource' (Agrawal 
and Ostrom 2001), which could include tree planting, timber management or conversion to agriculture. It is more than a use right, because it involves planning and intent for future use. Exclusion is the right to decide who can use the resource and who is prevented from doing so. Alienation is usually understood as the sale or lease of the land, which also includes the transfer of the other rights.

The bundle is also likely to include a combination of rights that are defined by statutory law (de jure) and rights that are defined locally, through de facto or customary institutions.

\section{The nature and origin of reforms}

Land reform is nothing new, but forest tenure reform differs in important ways from past agrarian reforms or even current market-based land reforms:

- rather than redistributing land, it most often formally recognises the rights of people already occupying the land;

- rights are granted to collectives rather than individuals:

- forests are expected to be conserved, rather than cleared for agriculture, which may be a condition of the new rights;

- the right to alienate (sell) or mortgage the land is rarely granted.

Each of these distinguishing characteristics has specific implications for reforms. Communities likely had customary rights to these same lands and forests previously, as well as customary management practices. Collective rights

\section{Box 1. Research scope and methods}

In 2006, CIFOR, in coordination with the Rights and Resources Initiative, launched Improving Equity and Livelihoods in Community Forestry, a global research project at more than 30 sites in 11 countries. The project aims to understand the origins, nature and initial outcomes of this new 'forest reform' (see Figure 1).

Research was conducted using a common conceptual and analytical framework to guide data collection and analysis, and a variety of specific methods at multiple, nested scales. It had the simultaneous goals of studying forest tenure reforms and catalysing efforts waged by communities and their advocates to advance local control and sustainable forest management. Hence, countries and sites were chosen on the basis not only of the interest to research, but also of their potential importance for the action and policy goals. The national- and local-level research was undertaken whenever possible through partner organisations with extensive experience in the country or subregion.

The central spheres of research included the effects of tenure reform on resource access and decision making; the role of community organisations and networks, state regulations and markets; and outcomes measured in terms of livelihoods, forest condition and equity. The fieldwork took place in 'research sites', usually multiple villages, where a change in forest tenure rights had occurred, or was about to take place, and involved moving both to more local and to larger scales from each site. At the more local scale, the research examined socially and economically differentiated access to forest resources, institutional processes and mechanisms for sharing benefits within and among communities undergoing reform. Larger scales permitted the contextualisation of cases in broader socio-economic, political and ecological contexts. The resulting analysis is based on a wealth of information at different scales obtained through diverse entities and methods and covering a large variety of reforms in multiple contexts. 

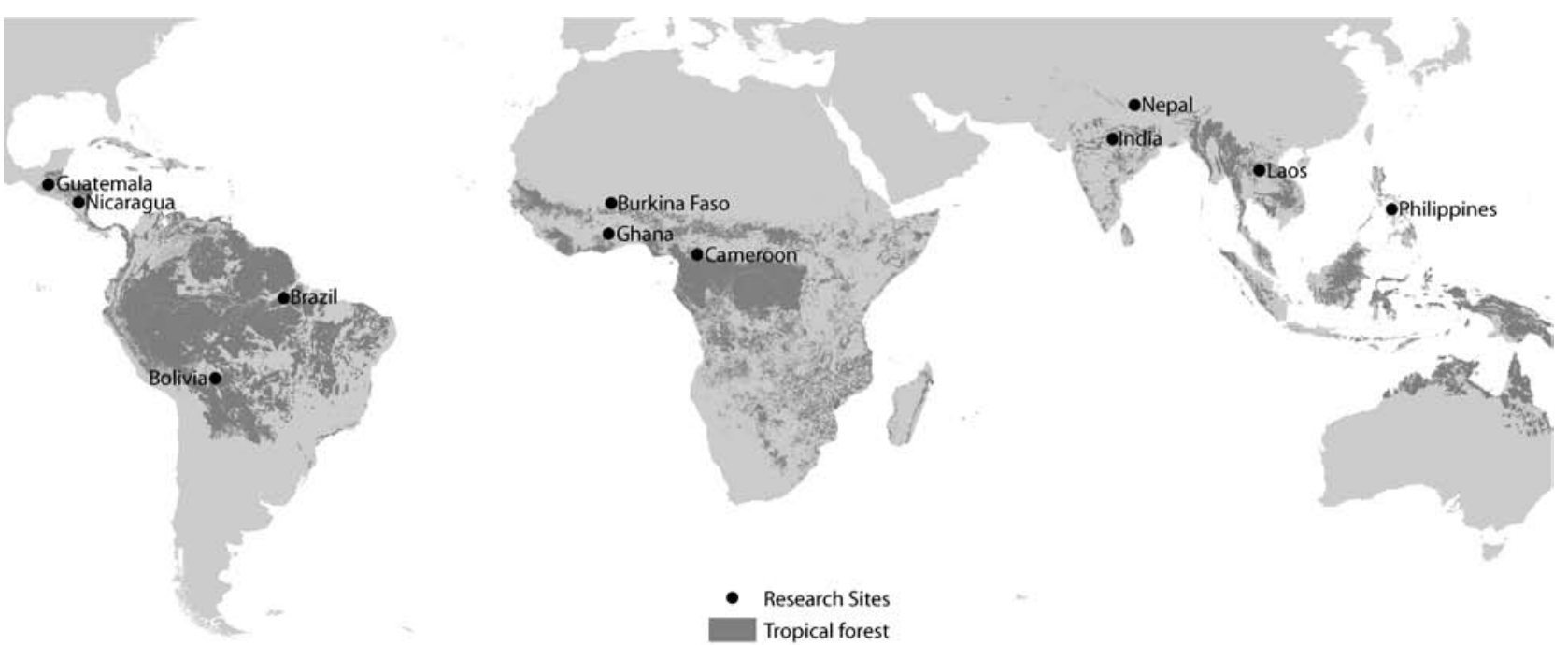

- Research Sites Tropical forest

Figure 1. Eleven countries with research sites for a global research project on forest reform, Improving Equity and Livelihoods in Community Forestry.

underscore the importance of structures of governance and issues of authority and representation; for example, rights may be granted at a scale different from the one at which people are currently organised, or the entity empowered to represent the collective may not be accountable to it. The concern for forest conservation means tenure rights are often combined with responsibilities, including heavy regulations or co-management arrangements that guarantee an ongoing role for the state. The lack of alienation rights means that recipients are prohibited from entering formal land markets.

The current forest tenure reform has emerged, in part, from challenges to centralised control of forests. Grassroots demands have emerged because people see opportunities to claim rights to forests that had historically been denied. This is particularly apparent among Latin America's indigenous movements, where demands for ancestral land rights are driving reforms, resulting in the single largest transfers of forest to local people. For example, in Brazil, indigenous rights were recognised for about 100 million ha involving 500000 people (Barr et al. 2002). The Bolivian government is in the process of titling nearly 24 million ha to benefit 200000 indigenous people (Pacheco 2006). These rights-based reforms have also opened up opportunities for other non-indigenous claimants, such as 145000 smallholders and extractivists allocated 20 million ha in Brazil (CNS 2005), or 13 communities granted forest concessions to 0.5 million ha in the Petén, Guatemala (Junkin 2007).

In Africa, and in some cases in Asia and Latin America, the main driver of reform has been decentralisation policies, though tenure reform was not necessarily among the goals of those policies. Decentralisation, in spite of the myriad ways in which it has been implemented, almost by definition affects tenure rights in public forests by altering the distribution of decision-making powers in the local arena, particularly where customary tenure rights are widespread. It has sometimes contributed to greater understanding and recognition of customary rights and practices, but it has also perpetuated and extended a colonial legacy to the state role in local management. Conflicts between statutory and customary systems have sometimes increased insecurity.

The third global force shaping reforms is the drive for biodiversity conservation, which has conditioned reforms in a variety of ways guaranteeing attention to forest conservation and providing opportunities for locals to push 
for unprecedented rights (as in the community forest concessions of the Petén, Guatemala), but also often ensuring the presence of strict use regulations that limit community decision making.

\section{The challenges of reform}

Forest tenure reforms range from fairly simple tree planting agreements and arrangements to share benefits from industrial logging, to a variety of community-based forest management schemes and even titling of large territories, though without alienation rights. What problems have occurred in the implementation of reforms? What rights have actually been granted?

One key issue is the extent of the legal change. Another is its permanence and security for the future. The central challenge is whether the new rights can be withdrawn, and (if so) how and under what circumstances. Property titles, such as those offered in some of the Latin American sites, or the guarantee of forest rights in perpetuity in Nepal, combined with constitutional provisions, appear to provide the greatest longterm security. (Titles may lead to other problems, however, especially where rights are complex and overlapping, and should thus not be assumed to be the best solution in all cases.) Rights granted through less binding instruments, such as decrees, regulations or contracts, are more tenuous, particularly if they can be unilaterally overturned. For example, the community of Mogotillos in the Guatemalan highlands negotiated control over a forest area through an agreement with the municipal government (the formal owner of the forest), but this can be easily annulled. Even the concession contracts in the Petén can be overturned for non-compliance, and do not establish any procedures for addressing compliance failures or recourse mechanisms. A number of additional challenges arise in the implementation of reforms.

Management rights and regulations. Though many reforms have granted a degree of local decision-making rights over forest management, the state also holds on to management rights in a number of ways. Hence, most reforms result in a kind of co-management, such that the state maintains important control over forest resources. This ranges from approving management plans and authorising extraction permits, to establishing forest management guidelines or more specific rules, requirements and use restrictions.

Co-management evolved from a criticism of command and control approaches, and is intended to promote greater state-community collaboration. But in terms of decision-making rights - that is, who has the final say over what - there may be little difference. Management arrangements often recognise some existing resource uses grounded in local livelihoods and customary practice, but also introduce new rules and standards and restrict certain previous activities. The resulting configuration can be quite complex. In general, however, the community has greater decisionmaking power over resources for domestic uses or over low-value resources (e.g., many non-timber forest products, NTFPs), while the state asserts greater control over commercial or higher-value resources (e.g., timber). For example, in Nicaragua and Guarayos (Bolivia), the state plays virtually no role in regulating domestic or NTFP uses, but requires complicated and detailed management plans for timber. In the Petén (Guatemala) and Pando (Bolivia), where logging plans are also required, there have been attempts to design management plans for NTFPs, specifically xate (Chamaedorea spp.) in Guatemala and Brazil nuts in Bolivia, both of which are exported.

Regulations and co-management arrangements are presumably intended to promote greater sustainability, but decisions sometimes appear arbitrary and fail to consider livelihood impacts. In Nepal, foresters are assigned to communities and have to review and approve all plans associated with forest use and management, as well as any changes to those plans. Foresters have a high degree of discretion, and some insist on applying 
restrictions that are even more stringent than the law. Since communities depend on these officials' approval for all forest activities, it can be difficult to challenge their decisions. As a result, forest user groups sometimes prefer to avoid logging, and particularly commercial sales of timber, because it keeps them under the state radar and allows greater autonomy. Foresters' rules can thus introduce disincentives and distortions, and limit local livelihood options.

Regulatory processes are notably bureaucratic. In the Philippines, obtaining a logging permit can take up to 6 months - since each permit is only valid for one year, this leaves only 6 months for logging. Also, concerns about community logging have resulted in the suspension of all the Resource Use Permits in the country on three occasions, even the Smartwood-certified and acclaimed Ngan Panansalan Pagsabangan Forest Resources Development Cooperative. Such actions generate instability and can cause substantial losses in what tend to be high-investment and low-profit operations.
Finally, some rules and regulations not only attenuate tenure rights, but also risk undermining previously effective local knowledge and management institutions and local livelihoods (see Box 2). They may foster illegal activities if obtaining legal permission is too difficult. Given the many problems, the challenge is to find better ways to support local autonomy and rights while both improving livelihoods and conserving forests.

Exclusion rights. Exclusion rights are granted in almost all cases and appear central to long-term decision making and resource protection. Three challenges are associated with this, however. First, communities may be granted these rights but be unable to enforce them, and the state often fails to provide support for this. In Nicaragua, for example, the state only intervened in the Layasiksa community's conflict with a colonist settlement inside its territorial claim after the community took the law into its own hands and someone was killed during a violent eviction; before this, Layasiksa's repeated appeals to legal and government institutions had fallen on deaf ears.

\section{Box 2. The risks of imposing statutory rules over customary practices}

Customary practices and traditional knowledge may decline under the influence of externally imposed rules, the consequences of which we may not know until it is too late. Transhumant pastoralism in Nepal's high hills is a way of life for ethnic groups such as the Sherpas, Bhote and Tamang, as well as a lucrative profession. It contributes to the national economy, and international trade, through the supply of milk, meat, draught animals and woollen goods. Pastoralists improve protection against forest fires and have superb ethnobotanic skills, traditional knowledge that may now be lost: herder populations are declining as they are being banned from grazing their animals in forest areas and forced into smaller regions. In one of our study sites, the population fell from $35-40$ prior to the establishment of the community forest to 16 at the time of the study.

In Guatemala, some highland communal forests have been managed for many years by indigenous institutions, but conservation organisations are interested in declaring protected areas there and establishing protected corridors between them. Though this is sometimes being done in coordination with local communities, it is not always clear what such a change of status will mean in terms of resource rights and rules. Limits on sheep grazing have hit women the hardest, and a prohibition on felling a popular Christmas tree, pinabete, has left at least one poor community in Los Cuchumatanes with few livelihood alternatives. In one study community, insecurity and conflict generated by a protected area declaration unleashed a series of land grabs. 
Second, granting exclusion rights to one group of customary users may mean taking use rights away from others. Thus, exclusion rights should not be assumed to mean that certain people should have exclusive rights. Where rights overlap and other poor, customary users also have traditional rights, it may be important to negotiate inclusion. This is what some mountain communities have done in Nepal to permit traditional herders to continue seasonal grazing in highland forests (mentioned in Box 2), though it has been insufficient.

Third, although communities may have the right to exclude other intruders, they may not have the right to exclude the state itself. In Burkina Faso and highland Guatemala, for example, the consent of the community is not required for the state to authorise licences to third parties in community forests. Though in most of the other cases studied communities are granted this right, it rarely extends to subsoil rights, such as petroleum prospecting and mining.

Competing interests. Even after forests have been granted to communities, these new rights holders are often subject to ongoing competition. This may involve land invasions by poor peasants; wealthy farmers and businesses interested in ranching, large-scale agriculture, biofuels or logging; mining or petroleum concessions; or the expansion of protected areas for conservation and tourism. How these conflicts play out depends, at least in part, on the effectiveness of community organisations and alliances, and on the role played by the state, including the implementation of the exclusion right mentioned above.

In a few cases, important state actors have backed the competition rather than communities. In Guarayos (Bolivia), for example, the forestry authority defended the claims of logging concessions on traditional lands claimed by the indigenous organisation COPNAG on behalf of the Guarayos people, undermining confidence in the titling process. In the Petén (Guatemala), the state initially backed a park expansion project that would have shut down several concessions - the Association of Forest Communities of Petén (ACOFOP) won a 3-year battle, costing about US\$100 000, to have this decision reversed.

Governance challenges. New rights may not reach all community members or even the community at all. It is sometimes assumed that communities already have appropriate institutions and mechanisms for resource access and control, and that reform will not affect existing institutions; hence, the issue may simply be ignored. Obtaining rights to a community forest in Cameroon is so bureaucratic and costly that communities often have to rely on local and sometimes external elites for funding, who then hijack the process and usurp the benefits. In Ghana, two measures to support benefit sharing from logging with forestfringe communities - the distribution of stumpage fees and social responsibility agreements - have been largely controlled by chiefs, and there is little indication that community members are benefiting. In indigenous territories, primarily in Latin America, new institutions usually have to be established at larger, territorial scales, which may then be a new site of struggle and conflict.

Alternatively, the state may require communities to form a new kind of organisation, such as an incorporated entity, in order to receive new rights. Particularly with regard to forest management, external agencies may establish new forest management committees in communities as well. These new entities are likely to overlap and compete with existing community governance structures, while shifting resource rights, priorities and income distribution. In the village of Carmelita, in the Petén (Guatemala), the concession organisation overlaid the governance structures that had built up around NTFPs and reoriented the community towards a new high-value resource, timber. In Layasiksa (Nicaragua), project proponents from WWF insisted that the traditional authorities were not appropriate for managing a community logging operation. Though both communities now run relatively successful forestry 
cooperatives, some of the tensions and conflicts could have been avoided with greater prior understanding of local social and cultural contexts.

\section{Accompanying measures. Accompanying} policies can facilitate the ability of communities to act on and obtain greater benefits from their new rights. These include capacity-building measures and the facilitation of market access. More often, however, state policies and bureaucrats impose cumbersome and costly regulations on the use or sale of forest resources. Reforms have also been limited by the forest resources granted to communities. In Cameroon, community forests are limited to the lower-quality domain of off-reserve forests; in Nepal, the high-value lowland forests of the terai are only rarely granted to communities.

When communities have had access to highervalue forests, combined with help to overcome hurdles such as bureaucracy, costly regulations and low capacity, they have sometimes been able to secure significant livelihood benefits from reforms. Community forestry enterprises engaged in commercial logging, for example, have annual profits ranging from US\$10 000 in one site in Cameroon to over $\$ 200000$ in one site in the Petén (Guatemala). Such enterprises are not possible, or necessarily even desirable, in all sites, however; for example, they may create external dependence and generate community conflict, and may not be sustainable beyond the life of the project. Nevertheless, these examples demonstrate what can be done under certain conditions and, in combination with other more modest outcomes, suggest that far more could be done to facilitate improvements in community livelihoods from forest tenure reforms.

\section{Outcomes of reform: livelihoods, forest condition and equity}

Given the wide variety of reforms and the numerous implementation challenges discussed, it is no surprise that not all reforms result in improvements in livelihoods, forest condition and equity. That is, not all reforms on paper have increased rights in practice; even when they have, numerous other variables have mediated outcomes. The analysis presented here is based on a qualitative assessment across cases aimed primarily at identifying those key variables (see Table 1).

Though it might be expected that older reforms have led to more substantial outcomes, this is not necessarily the case. In fact, identifying the starting date of a reform is not straightforward. For example, in the Nicaraguan case, which is not atypical, constitutional reforms in 1987 recognised indigenous rights to their traditional lands, but it took 15 more years to pass a law implementing that change, then another 5 years before the first land titles were granted; during those two decades, important changes took place in some communities but not others. Reforms that are clearly older and more consolidated have not necessarily had larger impacts. In the study of three tree-grower collectives in India, a majority of villagers stated that the benefits were 'unimportant' for their livelihoods.

Nevertheless, almost every community studied reported some kind of livelihood improvement, though this did not necessarily include income, or the entire population. Forest condition was more likely to improve in Asia and stay the same in Latin America, while the results across Africa were more varied. There were sometimes tradeoffs between livelihoods and forests. Perhaps most notably, however, though one might expect declines in forest condition with important livelihood improvements, these frequently did not occur.

Livelihoods and income. Tenure reform has opened up avenues for community access to new sources of goods for subsistence or income, but it has also sometimes involved new restrictions on the use of resources previously available to the community. This may mean bringing informal practices under regulation, as in the Kalahan reserve in the Philippines, or placing use 


\section{Box 3. Limitations on forest use in Brazil}

In the Brazilian municipality of Porto de Moz, in the state of Pará, local communities have a history of struggles with timber and fishing companies. To protect their land and natural resources, communities demanded the creation of an Extractive Reserve (RESEX). The resulting 'Verde para Sempre', covering some 1.3 million ha and including about 58 communities, was created in 2004 by presidential decree. Although the reserve secured the property rights of residents and allowed the communities to exclude timber companies from their lands, it also imposed new constraints on forest use for smallholders living in the reserve.

A RESEX is intended as an area where landholders develop extractive activities and small-scale agriculture. There are no limits on the collection of NTFPs, but other uses_such as logging (when allowed at all)_require a forest management plan. First, however, any activity to be developed in the RESEX must be part of a RESEX development plan. Five years after the declaration establishing the reserve, this plan still had not been written and approved.

Thus, despite grassroots mobilisation to create a reserve, the government's environmental and conservation objectives tend to dominate the interests of the local population. At the same time, state institutions are highly bureaucratic and ineffective in implementing their own rules. The current situation leaves local people little flexibility to use forest resources to fulfil their material needs - at least not legally.

restrictions on forests to allow for regeneration, as in all of the sites in Nepal. In these cases time is relevant, as use restrictions have been lifted as forests have recovered. The most important variables affecting livelihood outcomes are:

\section{What is the quality of the forests being assigned to communities?}

Many communities are given poor-quality forests with the expectation or specific mandate to dedicate their labour and resources to forest improvement. This is particularly common in the Asian cases and in Ghana.

\section{What are communities permitted to do with forests and forest resources?}

Regulations, strict oversight by the forest service and co-management arrangements often tie the hands of communities. Certain forest uses may be formally prohibited; norms may permit a degree of discretion that allows forest service personnel to place insurmountable obstacles in the community's way; or legal permits may be too expensive, confusing or time consuming to obtain. In Nepal, though there is an active timber market, communities are required to sell wood first within the community, then to neighbouring communities, and only then on the open marketevery aspect of planning has to be approved by a state forester (see also Box 3).

\section{What do communities have the capacity to do?}

Lack of access to credit, technology and market information may limit communities to subsistence uses of forest resources. In most of the cases demonstrating livelihood improvements, the reform did not simply change tenure rights, but also provided economic, technical and organisational support. These cases included all of the sites with logging enterprises, the community forest user group sites in Nepal, the Kalahan ancestral domain site in the Philippines, and the community concessions in Burkina Faso. Comprehensive external support has proved important for building community capacity, 
navigating the national bureaucracy and accessing markets, all of which affect livelihood outcomes.

Forest condition. Tenure reforms affected forest conditions in at least two ways. On the one hand, conditions were likely to improve when reforms gave communities rights over wastelands or forests in poor condition and prioritised conservation or regeneration under the rules of reform. On the other hand, forest condition appeared more likely to decline when the reform increased conflict, as in areas fraught with land grabbing in Guarayos (Bolivia), or led to elite capture, as in some cases in Cameroon. But intervening variables were also very important, particularly:

- Forests were maintained in sites where high dependence on agro-extractive activities generated an economic incentive to conserve the forest, and in communities with cultures strongly linked to forest maintenance;

- Conditions declined in communities close to colonisation areas, or in other areas with competing interests in forests and problems beyond community control, such as population growth.

Equity. Equity has multiple dimensions - the research looked specifically at the participation of poor people and women in decision making and benefit distribution. The findings provide little indication that increased tenure rights alone have a positive effect on equity.

In several cases, securing rights to one group involved ignoring the rights of others, as with herders in the highland forests of Nepal. In other cases, community members themselves defined 'the community' to exclude certain groups, as when Bantu communities in Cameroon have excluded Pygmies. These inequities often involved resident populations versus non-resident or seasonal resource users. Rights associated with substantial responsibilities or resource use restrictions sometimes adversely affected poor populations most, such as the banning of sheepherding in highland Guatemala.
Efforts to include women show only very slow progress. Women participate very little in groups organised on the basis of one representative per family, as in the tree-grower cooperatives in India, and in logging enterprises. For example, in Layasiska, where at least some part-time jobs were available for virtually all able-bodied men, only two women worked in the enterprise, as cooks.

The central finding is that positive outcomes for equity appear to depend on specific, dedicated efforts to address sources of inequity. It is notable that the most significant attempts to take poor people's interests into account were in Nepal, a country undergoing massive political upheaval and a place where a powerful discourse of inclusion and overcoming traditional inequities has taken hold.

\section{The future of reforms}

In the wake of past forces driving the centralised control over forests and forest resources, the case studies demonstrate that the recognition of tenure rights has offered new opportunities for communities living in and around forests. This change represents a first and vital step - an initial platform that better positions communities - in the ongoing demand for greater and more secure rights, particularly with regard to state forest bureaucracies.

The granting of rights has been highly controlled, unevenly implemented and subject to competition from more powerful actors - all of which have worked to attenuate community gains. Even when there has been a concerted effort for the statutory reforms to respond to local demands and accommodate customary practices, they often fail to do so, because the scale of the reform may not match the scale of representative authority, or because vesting statutory powers in chiefs or traditional authorities does not always benefit the community as a whole. Still, advances in rights have sometimes been significant, as have improvements in income benefits and forest 


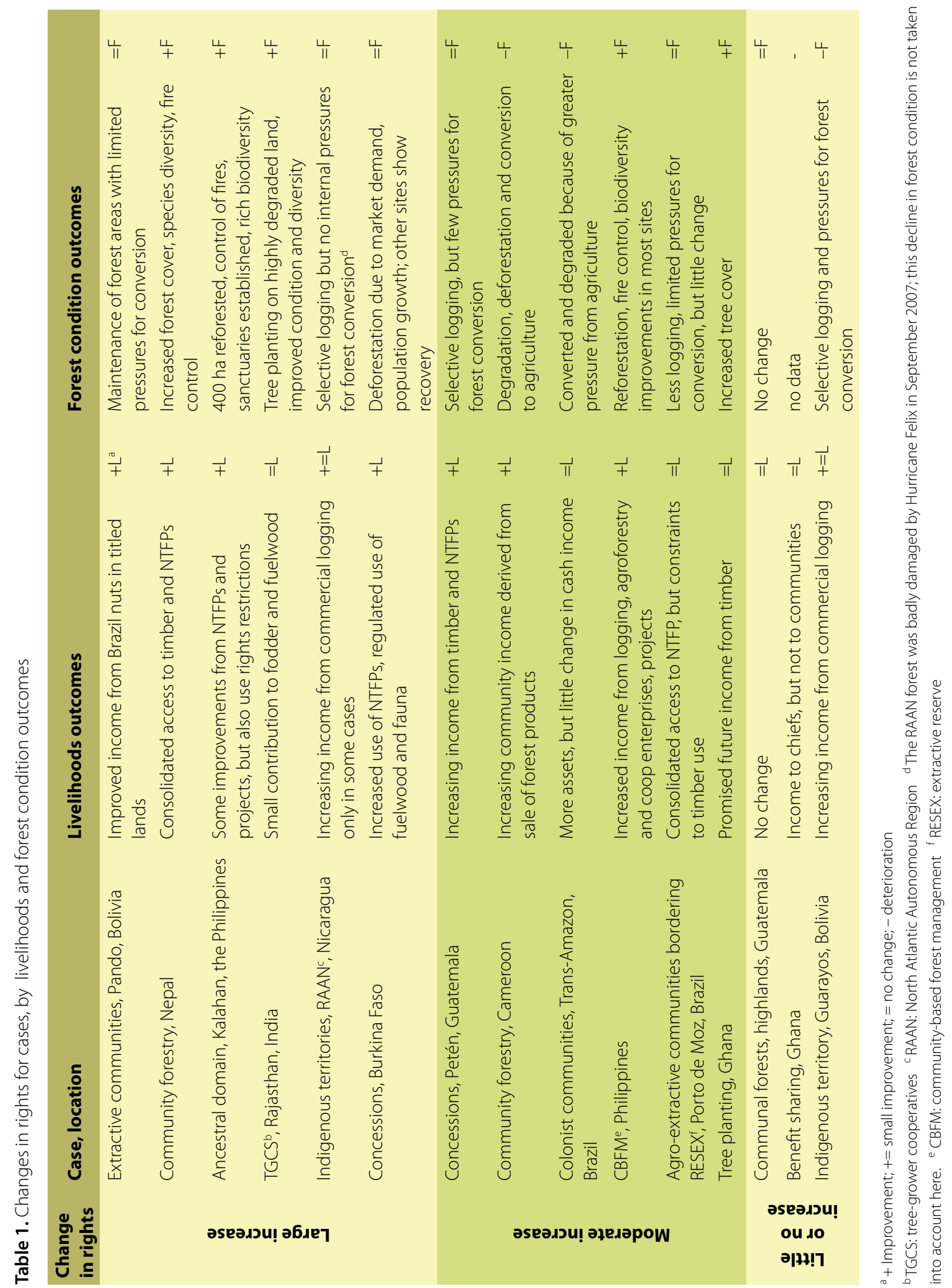


condition in a few cases; almost all of the sites found some kind of livelihood gain to celebrate without declines in forest condition (see Table 1).

Improved outcomes from forest tenure reform require:

- the full implementation of reforms;

- the granting of higher-quality forests and rights, rather than simply low-quality forests and responsibilities;

- state support in the defence of community exclusion rights, as well as the negotiation of responsible inclusion for other poor and marginalised groups;

- new experiments in regulation and comanagement, such as a revamped and simplified regulatory framework that builds on community strengths, rather than overriding effective local practices and institutions where these exist;

- full development of accompanying measures, such as capacity building and support for market engagement, that enable communities to obtain benefits beyond the simple granting of rights;

- the inclusion of clear, specific equity goals, targets and monitoring systems from the design of reforms through implementation, probably including a certain degree of positive discrimination;

- attention to representation and accountability of those acting on behalf of communities;

- support to local organisations and larger-scale networks and federations, which are essential to building a political climate for the promotion, defence and deepening of reforms.

When forest tenure reform aims to support customary rights and practices, policy makers should analyse the ways in which these practices can be accommodated and incorporated into the reforms, such that these, rather than external norms, become the basic building blocks of forest conservation and livelihood improvement. That is, rather than starting from the perspective of state regulation, we propose starting from communities: What are the local needs and practices, and what potential do they have for sustainable, grassroots forest management?

Evidence to date suggests that there are numerous ways in which some sectors of the state may seek to control, limit or reverse reforms in rights, and in which other competing claimants may encourage such actions for their own benefit. There is no evidence that the battle is over once the new rights are won - rather, the struggle for change is subject to ongoing challenges, and thus requires ongoing reinforcement.

\section{Endnotes}

1 This brief uses the term 'community' to refer to both indigenous and non-indigenous groups. The community was the basic unit of analysis across all sites. Community is defined as those who share a common interest or purpose in a particular forest and share common resources. Hence, a residentbased community (or village) may overlap with a community of interest or be a subset of it, or vice versa. Local communities may be embedded in larger communities. Community does not include individuals and firms.

\section{References}

Agrawal, A. and Ostrom, E. 2001 Collective action, property rights, and decentralization in resource use in India and Nepal. Politics and Society 29(4): 485-514.

Barr, C., Brown, D., Casson, A. and Kaimowitz, D. 2002 Corporate debt and the Indonesian forestry sector. In: Colfer, C.J.P. and Resosudarmo, l.A.P. (eds) Which way forward? People, forests and policymaking in 
Indonesia. CIFOR and Resources for the Future, Washington, DC.

CNS 2005 Populações extrativistas da Amazônia: processo histórico, conquistas sócio-ambientais e estratégia de desenvolvimento econômico. Conselho Nacional dos Seringueiros, Belém, Brazil.

Junkin, R. 2007 Overcoming the barriers to financial services for small-scale forestry: the case of the community forest enterprises of
Petén, Guatemala. Unasylva 228(58): 38-43.

Pacheco, P. 2006 Acceso y uso de la tierra y bosques en Bolivia: sus implicaciones para el desarrollo y la conservación. UDAPE, La Paz, Bolivia.

Sunderlin, W., Hatcher, J. and Liddle, M. 2008 From exclusion to ownership? Challenges and opportunities in advancing forest tenure reform. Rights and Resource Initiative, Washington, DC.

The information for this brief was drawn from the forthcoming 'Forests for people: Community rights and forest tenure reform' edited by A.M. Larson, D. Barry, G.R. Dahal and C.J.P. Colfer, to be published by Earthscan in 2010. CIFOR plans to publish the Spanish translation in 2010 as well.

Center for International Forestry Research

CIFOR advances human wellbeing, environmental conservation and equity by conducting research to inform policies and practices that affect forests in developing countries. CIFOR is one of 15 centres within the Consultative Group on International Agricultural Research (CGIAR). CIFOR's headquarters are in Bogor, Indonesia. It also has offices in Asia, Africa and South America. 